\title{
VISUAL ILLUSTRATION AND PHOTOGRAPHY ON ISLAMIC BOOK COVER DESIGNS: A SEMIOTIC ANALYSIS
}

Accepted date: $14-03-2019$

\author{
Mohamad Suhaizi Suhaimi ${ }^{1}$ \\ Universiti Putra Malaysia \\ (Email: suhaizisuhaimi@yahoo.com) \\ Muhammad Faizuddin Hashim ${ }^{2}$ \\ Universiti Kebangsaan Malaysia \\ (Email: faizuddinhashim@gmail.com) \\ Sharil Nizam Sha' $\mathbf{r i}^{3}$ \\ Universiti Putra Malaysia \\ (Email: sharil@upm.edu.my)
}

Published date: 10-07-2019

To cite this document: Suhaimi, M. S., Hashim, M. F., \& Sha'ri, S. N. (2019). Visual Illustration and Photography on Islamic Book Cover Designs: A Semiotic Analysis. International Journal of Heritage, Art and Multimedia, 2(5), 34-41.

DOI: $10.35631 /$ ijham. 25003

\begin{abstract}
The publication of religious books recently has been in line with the publication of books of other genres. It is because of the increase in the demands by the readers in addition with the design of the book covers which has been made up more interesting. Hence, this research was aimed to identify the influence of visual illustration and photography displayed on book covers which preferred by the readers. Sign theory by Peirce (1839) and Semiotic Analysis by Stokes (2003) were applied for the purpose of data analysis. A book published by Telaga Biru Sdn. Bhd. entitled Ikon Syabab by Umar Muhammad Noor (2014) has been made as the research data focusing on the taxonomy aspect of its cover. The results showed that the proper use of pictures was undeniably able to attract the readers to buy the religious book currently in the market. This research also was predicted to be able to contribute to the national socio-economic interest, generate a rich cultural society and elevate the percentage of book publication in Malaysia.
\end{abstract}

Keywords: Semiotic, Illustration, Photography, Design, Book Cover, Islamic

\section{Introduction}

The publication of religious books in Malaysia has shown a comparable growth with the publication of other books. This could be proven with the domination of religious section in most bookstores with the percentage of 20 to 50 percents of floor space with such books (Mohamad Azmie Zakaria, 2015). Other than media sources like television and radio, it is undeniable that religious books are also preferred by the society as a source to learn about Islam as it is also influential in the dakwah movement. In addition, reading religious books 
also had caused many youths and civil servants to recognize Islam (Nurhafiza Hamzah, 2016). Therefore, dakwah-oriented writing is capable of providing useful impacts to the readers.

The creation of the book covers generally is made up of three parts, which are the front cover, the back cover and the spine (Hamedi Mohd. Adnan, 2008). All these three parts have their own significance and are the first element to be observed by the readers. In case of a religious book cover, the design and phenomenon that could be seen are focusing more on Islamic elements. For instance, designs of the mosque dome, rehal (book rest), and soft colours choice illustrates the Islamic features itself which are perfect and beautiful.

Book cover designs are created from the process of arranging typography and visual (Hanafi Tahir, Normah Mustaffa, Wan Amizah Wan Mahmud (2017). Visual is an important element in the graphic design arts which highly contributes in the publication processes of materials such as books, magazines, posters and others. Hence, visual through illustration and photography are effectively used in the process of designing and arranging printed materials. As supported by Parker (2006), illustration and photography are the most important visual elements used in the publication process of any material.

It is believed that when a book is translated to a target language it will be adjusted to the social and ideological factors that are dominant in the target society. One of the items that will be adjusted, is the image and graphic design of the cover of the books. Also, in procedure of translation of a book we can find traces of power relations and ideological implications. Book jackets began to gain importance in the 1890s with the recognition that they could be a way to attract the attraction of potential buyers. The cover has little about the genre of the text. The cover conveys the content, the atmosphere and the setting of the text. This cover employs symbols derived both from the text and outside of the text in a very simple manner. Overall, the relationship of integrity between the cover and the text can be graded as medium. Cover design is a type of intersemiotic translation and develops a method of analysis and evaluation to assess how accurate these translations are. Book cover designs are profoundly influenced by several factors like the cultural and social features of the target audience, market, and the publisher's own opinions and interests (Sonzogni, 2011).

This research has chosen the design book cover of Ikon Syabab by Umar Muhammad Noor (2014) as the research data to observe the illustration and photography element applied. It was chosen as it has been listed as one of the best seller books published by Telaga Biru Sdn. Bhd. (http://www.telagabiru.com.my/bestseller). In addition, this was the only book which had the combination of illustration and photography in its cover design among all other best sellers. Moreover, Telaga Biru Sdn. Bhd. has won National Book Awards 2012 (Malaysia) in the best religious book category, Prime Awards: The Best Publisher (private) category in 2015 and The Best Religious Book category in 2016. Therefore, achievements in these national book rewards have proved the eligibility of this publication as a source and material of research as the winners were chosen and judged by professional judges. 


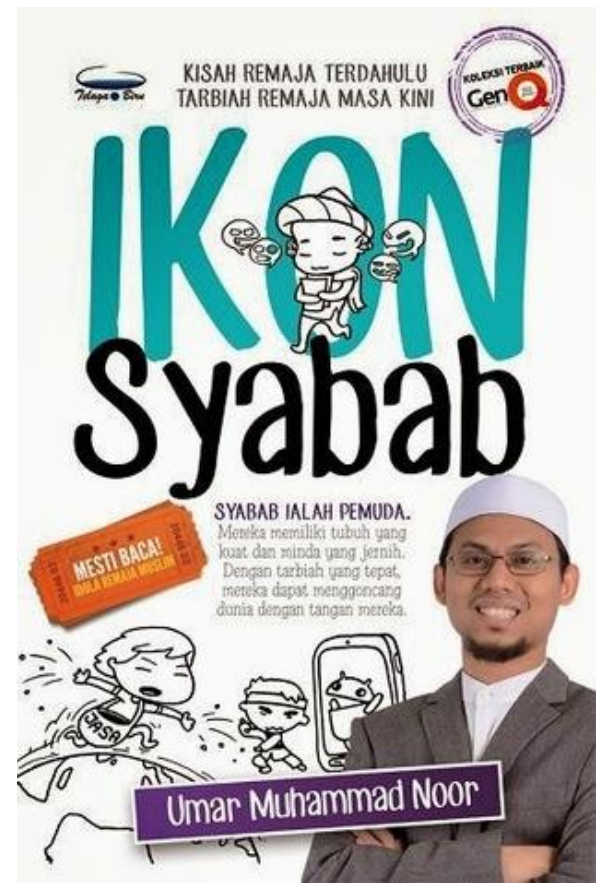

Figure 1: Book Cover of 'Ikon Syabab'

\section{Problem Statement}

Logo sign can be a main factor in credity and bestselling books (Salmani \& Eghtesadi, 2015). Therefore, the design of book cover is examined as one of the criteria actively involved in the reading of the text not as a marginal factor. Thus, cover of a book conveys a message about the contents of the volume, influencing both the retailer who stocks the book and the potential purchaser in market. Different book design of certain works done during different sociohistorical circumstances certainly demonstrate the prevailing ideological stances to some extent.

The research on cover design has been done toward various book such as novel, fiction genre and others. But, there are few research focus on Islamic cover book design in Malaysia. Hence, by applying different aspects of semiotic approach, it can intended to shed light on various ideological impacts especially in Islamic book cover designs.

\section{Research Objective}

This research focuses on two objectives, which:

i. To identify the elements of visual illustration and photography on the design of book cover Ikon Syabab

ii. To analyse the semiotic signs on the design of book cover Ikon Syabab.

\section{Semiotic Theory}

Studies of meaning evolve from semiotics, a philosophical approach that seeks to interpret messages in terms of their signs and patterns of symbolism. The study of semiotics or semiology in France, originated in a literary or linguistic context and has been expanding in a number of directions since the early turn-of-the century work of C.S. Pierce in the United State and Levi Strauss and Ferdinand Saussure in France. Saussure (1983) divides linguistic signs into two components- the signifier (the sound, image, or word) and the signified, which is the concept that the signifier represents, or carries the meaning. As Berger (2004) points out, the problem of meaning arises from the fact that the relation between the signifier and the signified is arbitrary and conventional. In other words, signs can mean anything, and they can 
mean different things to different people. The distinction is true in most written and spoken language; however it is clear that visual signs are not arbitrary (Chandler, 2007). This phenomenon differentiates between the first order and a second order creation of meaning. The first-order imputation of meaning, at the level of denotation, produces the sign function of the object - i.e., meaning according to its immediate function. The second order imputation of meaning, or the connotative meaning, signifies its social context. It is this level that transfunctionalizes the object to socially prescribed meanings (Gottdiener, 1995).

\section{Research Methodology}

This research was carried out based on the semiotic theory by Peirce (1839-1914) which was triadic and explained through taxonomy element of book cover. Peirce (1839-1914) stated that signs are the representatives and objects are concepts, items or ideas. Meanwhile, meanings are perceptions, thoughts and feelings attained from a sign termed as 'interpretation' (Danesi, 2004). Sign model proposed by Peirce (1839-1914) was tricotomy or triadic. According to Peirce, sign interpretation denoted to the relationship between three points which were Representative $(\mathrm{X})$, Object $(\mathrm{Y})$ and Interpretation $(\mathrm{X}=\mathrm{Y})$. $\mathrm{X}$ is a sign part which can be perceived physically, by referring to something represented by $\mathrm{Y}$, then $\mathrm{X}=\mathrm{Y}$ is a part from the process of explaining the relationship between $\mathrm{X}$ and $\mathrm{Y}$.

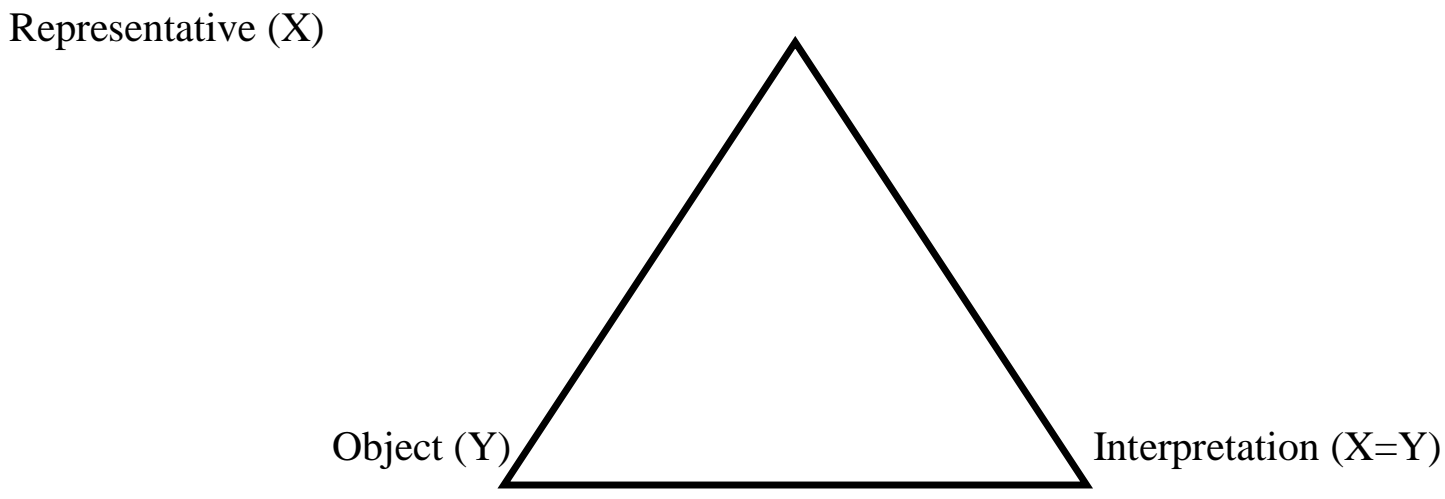

Figure 2: 'Peircean' Signs

For data analysis, semiotic analysis according to Stokes (2003) was applied starting with defining the analysis object and group of signs that will be analysed which was the book cover of Ikon Syabab. Next, the visible signs on the book cover were analysed and listed. In the Semiotic Analysis by Stokes (2003), there were four dimensions of physical elements, consisted of (1) shape, (2) colour, (3) picture, and (4) writing and message as in Figure 3. However, it has been limited to only picture element for analysis in the research, as this research only focused on visual illustration and photography. In the next stages, the results of taxonomy analysis on the book cover were explained as an interpretation based on Sign theory by Peirce (1839-1914). 


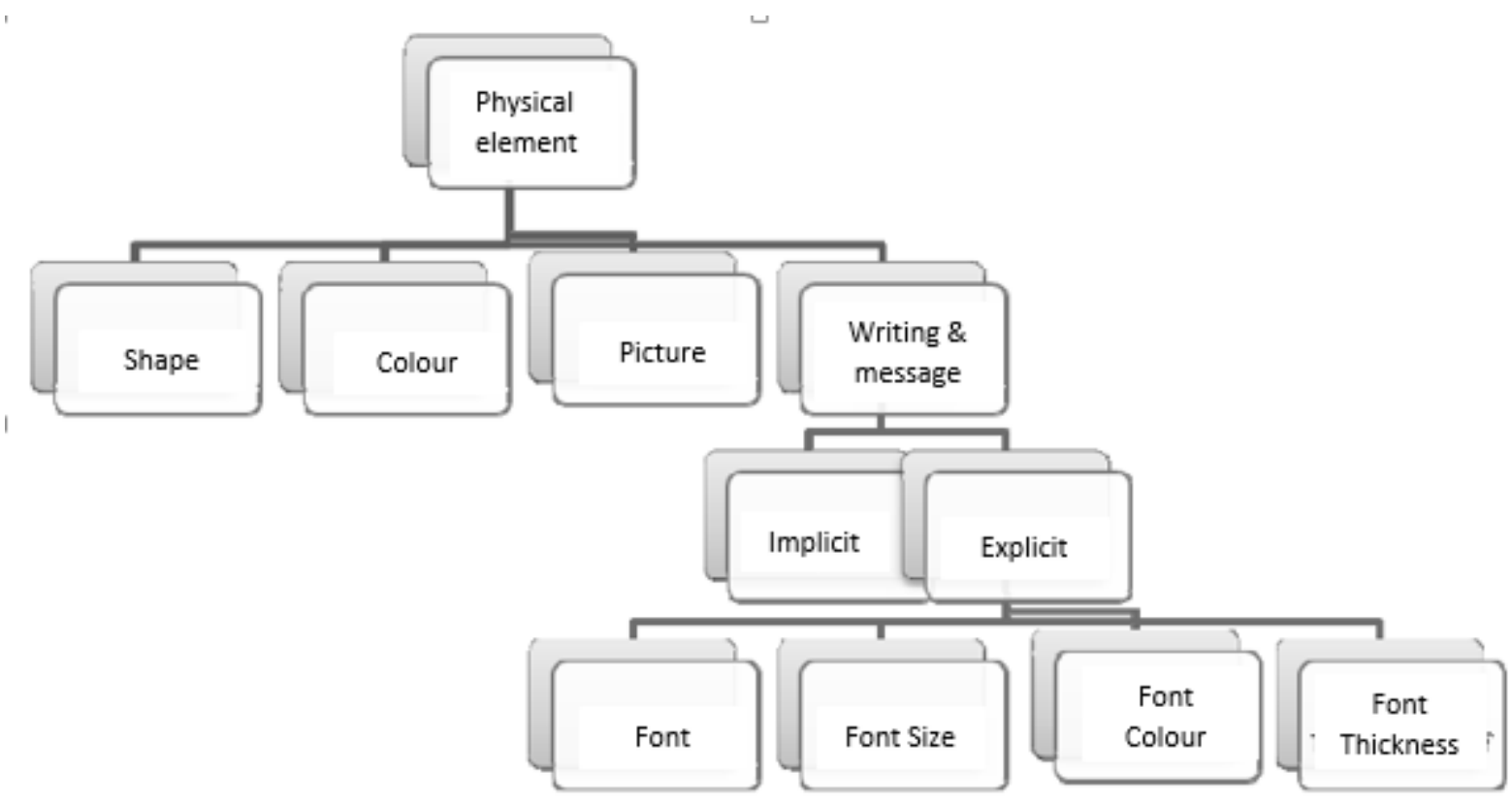

Figure 3: Semiotic Analysis by Stokes (2003)

\section{Research Analysis}

Book cover is the first thing to be noticed by the readers. The whole overview of the book content is transformed into the cover design of the book. Therefore, the book Ikon Syabab presented a combination of visual illustration and photography on its cover.

In this research, the picture element was divided into two parts, which were photography and illustration. For illustration, the picture presented were animations of three youngsters of different characters with smartphones. Meanwhile, for photography, there was only one picture element presented which was the writer's photo. Interpretations towards the picture elements on the design of book cover Ikon Syabab were as in the following table:

Table 1: Interpretation of Picture Elements on the Islamic Book Cover Design

\begin{tabular}{|l|l|l|l|}
\hline $\begin{array}{l}\text { Picture } \\
\text { Element }\end{array}$ & Representative (X) & Object (Y) & $\begin{array}{l}\text { Interpretation (X=Y) } \\
\text { Illustration }\end{array}$ \\
$\begin{array}{l}\text { young boy wearing } \\
\text { turban surrounded } \\
\text { by negative elements }\end{array}$ & $\begin{array}{l}\text { A youngster being } \\
\text { tempted }\end{array}$ & $\begin{array}{l}\text { Illustration of a } \\
\text { youngster wearing turban } \\
\text { surrounded by negative } \\
\text { elements indicated that } \\
\text { youngsters today easily } \\
\text { influenced by temporary } \\
\text { worldly temptation. At } \\
\text { the young stage of ages, } \\
\text { one's identity is shaped } \\
\text { either towards positivity } \\
\text { or negativity. The image } \\
\text { of a youngster with } \\
\text { turban also illustrated } \\
\text { that even ones with } \\
\text { strong faith would not be } \\
\text { excluded from being } \\
\text { tested and tempted. }\end{array}$ \\
\hline
\end{tabular}




\begin{tabular}{|c|c|c|c|}
\hline & $\begin{array}{l}\text { Animation of a } \\
\text { young boy walking } \\
\text { on an earth holding a } \\
\text { sack of } \\
\text { 'contribution'. }\end{array}$ & $\begin{array}{l}\text { A youngster } \\
\text { disseminating } \\
\text { contributions on } \\
\text { earth. }\end{array}$ & $\begin{array}{l}\text { Illustration of a } \\
\text { youngster who is } \\
\text { walking while holding a } \\
\text { sack of 'contribution' } \\
\text { showed that a youngster } \\
\text { also needs to contribute } \\
\text { in his life. Among the } \\
\text { things that can be } \\
\text { contributed are doing } \\
\text { good to their parents } \\
\text { until the end of their } \\
\text { lives, being beneficial to } \\
\text { the society and taking } \\
\text { care of the environment. }\end{array}$ \\
\hline & $\begin{array}{l}\text { Animation of a } \\
\text { young boy practicing } \\
\text { 'silat'. }\end{array}$ & $\begin{array}{lr}\text { A } r & \text { youngster } \\
\text { practicing martial } \\
\text { arts for self- } \\
\text { defence. }\end{array}$ & $\begin{array}{l}\text { Illustration of a } \\
\text { youngster practicing } \\
\text { 'silat' showed that } \\
\text { everyone should practice } \\
\text { martial arts to defend } \\
\text { themselves from the } \\
\text { enemies both tangible or } \\
\text { untangible. For tangible } \\
\text { enemies, they have to } \\
\text { defend themselves } \\
\text { physically. Meanwhile, } \\
\text { for intangible enemies, } \\
\text { they have to defend } \\
\text { themselves spiritually } \\
\text { such as by practicing } \\
\text { solat, dua, and zikr. } \\
\text { Other than self-defence, } \\
\text { the animation also can } \\
\text { portray the youngsters } \\
\text { should be involved in } \\
\text { healthy and beneficial } \\
\text { activities in their lives. }\end{array}$ \\
\hline & $\begin{array}{l}\text { Animation of a } \\
\text { smartphone }\end{array}$ & $\begin{array}{l}\text { The latest medium } \\
\text { of interaction used } \\
\text { especially by the } \\
\text { youngsters }\end{array}$ & $\begin{array}{l}\text { Smartphone is a medium } \\
\text { of interaction and } \\
\text { communication } \\
\text { commonly used by } \\
\text { everyone including the } \\
\text { youngsters. The use of } \\
\text { smartphones has its own } \\
\text { advantages and } \\
\text { disadvantages based on } \\
\text { the users' ways of using } \\
\text { it. }\end{array}$ \\
\hline Photography & $\begin{array}{l}\text { Photo of a man } \\
\text { wearing 'kopiah'. }\end{array}$ & $\begin{array}{l}\text { The book writer } \\
\text { named } \quad \text { Umar } \\
\text { Muhammad Noor }\end{array}$ & $\begin{array}{l}\text { The man wearing white } \\
\text { 'kopiah', who is the } \\
\text { writer of the book, }\end{array}$ \\
\hline
\end{tabular}




\begin{tabular}{|l|l|l|}
\hline & $\begin{array}{l}\text { showed the genre of the } \\
\text { book, which is religion } \\
\text { and written by religious } \\
\text { person Usually, the } \\
\text { photo of the writer is } \\
\text { allocated at the book } \\
\text { cover to attract the } \\
\text { buyers as well as his } \\
\text { followers. }\end{array}$ \\
\hline
\end{tabular}

The results indicated that both visual illustration and photography are equally important. Both visuals play roles to explain the meaning and information to the targeted audience. The appearance of visual illustration and photography on the book cover purposes to explain the main idea and content of a book. Interesting visual appearance will be able to attract the attention of the targeted audience.

\section{Conclusion}

In conclusion, the research data from this study is flexible. This situation gives advantages to this research as the data collected are able to be explained in descriptive and changeable according to the research suitability and necessity. The data collected regarding this discussion described a few tails of interpretations that can be attained from visual illustration and photography of the book cover. Seemingly, the combination of visual illustration and photography has the potential to attract the audience as well as to contribute in the selling of religious books in Malaysia.

\section{References}

Berger, A. A. (2004). Shop'til you Drop: Consumer Behavior and American Culture. Maryland: Rowman \& Littlefield Publishers.

Chandler, D. (2007). Semiotics: The Basics. London: Routledge.

Danesi, M. (2004). Message, Sign, and Meanings: A Basic Text Book Insemiotics and Communication Theory. Toronto: Canadian Scholar's Press.

Gottdiener, M. (1995). Postmodern Semiotics: Material Culture and the Forms of Postmodern Life. Oxford: Blackwell.

Hamedi Mohd Adnan. (2008). Memahami Penyuntingan Naskhah. Bangi: Medium Publication.

Hanafi Tahir, Normah Mustaffa \& Wan Amizah Wan Mahmud. (2017). Kemudahbacaan Visual Ilustrasi dan Fotografi pada Reka Bentuk Kulit Buku. International Conference on Media and Communication. Putrajaya.

Mohamad Azmie Zakaria. (2015, September 30). Utusan Malaysia. Mampukah Buku Akademik Jadi Buku Agama, 11.

Nurhafiza Hamzah. (2016). Penerimaan E-Buku Agama Sebagai Medium Dakwah dalam Kalangan Pelajar dan Pensyarah Universiti Tun Hussein Onn Malaysia. Master Thesis. Universiti Tun Hussein Onn Malaysia.

Parker, L. (2006). Never Judge A Book by Its Cover: A Visual Argument. WRA 360.

Saussure, F. D. (1983). Course in General Linguistics. New York: McGraw-Hill.

Salmani, B \& Eghtesadi, Z. (2015). An intersemiotic approach towards translation of cover designs in retranslated classic novels. Theory and Practice in Language Studies, Vol. 5 (6), 1185-1191.

Sonzogni, M. (2011). Re-Covered Rose: A Case Study in Book Cover Design as Intersemiotic Translation. Amsterdam: John Benjamins. 
Stokes, J. (2003). How to Do Media and Cultural Studies. London: Sage Publication. Umar Muhammad Noor. (2014). Ikon Syabab. Kuala Lumpur: Telaga Biru Sdn. Bhd. 